\section{Income inequality and adolescent fertility in low-income countries}

\author{
Desigualdad de renta y fertilidad en la \\ adolescencia en países de baja renta
}

\section{Desigualdade de renda e fertilidade na adolescência em países de baixa renda}

Ruben Castro 1

Eduardo Fajnzylber 2

doi: 10.1590/0102-311X00203615

\section{Correspondence}

R. Castro

Instituto de Politicas Públicas, Universidad Diego Portales. Ejercito \#260 Santiago de Chile, Santiago / Metropolitana 8370056, Chile.

ruben.castro@udp.cl

1 Instituto de Politicas Públicas, Universidad Diego Portales, Santiago, Chile.

2 Escuela de Gobierno, Universidad Adolfo Ibañez, Santiago, Chile. e and controls to the Demographic and Health Surveys data. A tive association between income inequality and adolescent fertility was found among low-income countries, controlling for income (OR $=0.981 ; 95 \% \mathrm{CI}$ : 0.963-0.999). Different measures and different subsamples of countries show the same results. Therefore, the international association between income inequality and adolescent fertility seems more complex than previously thought.

Social Inequity; Fertility; Developing Countries; Adolescent 


\section{Introduction}

The well-known socioeconomic gradient in health does not imply that income inequality by itself has any effect on well-being. There is great controversy regarding the possible harmful effects of inequality on well-being 1,2,3,4,5,6,7,8. Many studies found no income inequality-well-being association, as has been reviewed in the literature 2,4 . The recently released third version of the Social Science Index 9 , a global collection of well-being measures, shows no association between these measures and income inequality. Basically, "whether or not the scale of a society's income inequality is a determinant of population health is still regarded as a controversial issue" 2 (p. 1768). It seems that the empirical association depends on the sample setting, measurement, and time period 1.

At the same time, there are many dimensions where a clearer impact of income inequality on well-being is found, many of them among the younger members of the population. Findings include the impact of income inequality on violence, homicide rates, abortion rates, and other dynamics that are characteristic of young individuals. In fact, the association between income inequality and agespecific death rates, the most common measure of well-being in this field of research 3,4,5, appears stronger among young or adolescent subpopulations than among any other age group 10. Additionally, the overall international relation between income inequality and health is more stable across time amongst youth 2 .

Adolescent fertility is one dimension of adolescent health in which the income inequality-wellbeing association is being studied. Five articles explore the income inequality-adolescent fertility relationship across countries, and all of them find a positive and statistically significant association $11,12,13,14,15$; i.e., with greater income inequalities, higher rates of fertility are found. This is important because adolescent fertility is one of the most influential dimensions of adolescent health for researchers and policy makers. Adolescent fertility, for example, is the variable with the closest relationship to the overall United Nations Children's Fund (UNICEF) child well-being index 11, as well as a strong determinant of future outcomes 16,17 and a strong population-level predictor of life expectancy and infant mortality rates 18,19 .

However, this evidence of a positive income inequality-adolescent fertility association (a) does not include individual-level measures of income, as recommended in the literature 6,7,20, to distinguish the concavity (in the income-to-health relation) induced effect of income inequality on adolescent fertility from the "true" contextual effect of income inequality on adolescent fertility, and (b) comes mostly from analysis of middle-income to rich countries. Only two studies 12,13 include low-income countries in their overall sample, and none of them perform subsample exercises or include interactions between income inequality and average income. The first study 12 is not focused on adolescent fertility specifically, but on ten domains of adolescent health, while the second 13 has only an abstract available. In general, "further work is needed to examine whether these relationships hold in all regions and country income groups" 13 (p. S5). At the national level, one available study in a developing country found a positive association between Brazilian municipalities 14, and another found evidence of a negative association across time in Philippines 21.

This study aims to measure the international association among countries with low income. This adds a piece of evidence to the conceptual and empirical research about the effect of income inequality on adolescent fertility and, more generally, on well-being. This study performs a statistical analysis of the income inequality-adolescent fertility country-level relationship in a sample of low-income countries. It applies a multilevel logistic regression of country-level adolescent fertility on country-level income inequality plus individual-level income and controls to the Demographic and Health Surveys (DHS) data.

The focus at country-level income inequality, instead of smaller area-level income inequality, comes from the international perspective taken in this study. Moreover, country-level analysis tends to find stronger income inequality-to-health associations 1 than smaller-area ones, thus providing a stronger basis for the study of this association.

As said, the inclusion of individual-level measures of income tries to capture concavities in the income-to-health relation, which might otherwise introduce a spurious income inequality-to-adolescent fertility association. The use of multilevel data is essential for testing the contextual effect of income inequality $6,7,22$. 


\section{Material and methods}

Excluding the surveys conducted before 1990, there are 218 DHS, in which all the 131 surveys that contain the relevant birth and wealth data are kept. The DHS program (http://www.dhsprogram. com) is a long-standing initiative that conducted mostly nationally representative surveys on about 90 countries with relatively low income; it covers many topics and has a focus on health. The list of surveys in this study is detailed in Table 1.

In the country-level analysis, the adolescent fertility ratio is defined as the observed ratio of total children born over the total number of females. The total number of births per women is captured in the survey by separately asking about alive and not alive children. In the multilevel analysis, adolescent fertility is defined as a dichotomous variable capturing whether the individual has had at least one child or not. Stata 13 (StataCorp LP, College Station, USA) was used to conduct the analysis.

Country-level analysis includes mean income as control, because, ex ante, it is expected to have an association with adolescent fertility; GDP per capita is used as a measure of mean income due to its easy interpretation 23. The multilevel analysis also includes individual income as control; however, there is no simple measure of individual income in the data. The wealth index by the World Health Organization (WHO) is used here as a proxy for the socioeconomic position. Wealth is, among lowincome countries, a reasonable household-survey-based measure of socioeconomic level 24. The wealth index is calculated from a (first component of a) principal components analysis that places individual households on a continuous scale of relative wealth. As the wealth index is not comparable across areas, the measure included in the analysis is the relative position, from 0 to 1 , of each individual in the survey in the wealth index ladder. Since GDP per capita is included as control, this relative ranking is a reasonable proxy for the individual socioeconomic position. Details about the wealth index used here can be found at the World Bank 25 and DHS program websites 20, respectively.

Table 1

Descriptive statistics.

\begin{tabular}{|c|c|c|c|c|c|}
\hline Region & Latin America & Asia & Africa & Middle East & All \\
\hline Number of countries & 9 & 8 & 27 & 11 & 55 \\
\hline Number of surveys & 26 & 20 & 65 & 20 & 131 \\
\hline \multicolumn{6}{|l|}{ Averages } \\
\hline Sample size (female adolescents) & 1,882 & 1,526 & 977 & 444 & 1,145 \\
\hline Adolescent fertility: expected births during adolescence & 0.16 & 0.24 & 0.22 & 0.22 & 0.21 \\
\hline Adolescent fertility: proportion with at least one child & $17 \%$ & $15 \%$ & $22 \%$ & $12 \%$ & $18 \%$ \\
\hline Gini index (income inequality) * & 51.57 & 35.58 & 43.13 & 34.47 & 42.34 \\
\hline Average income ** & 6,466 & 3,642 & 2,502 & 7,232 & 3,765 \\
\hline
\end{tabular}

* Data from the World Bank 25;

** GNP per capita, purchasing power parity (current international \$) from the World Bank 25.

Note: the list of surveys is: Albania (2008), Angola (2006), Armenia (2000, 2005, 2010), Azerbaijan (2006), Bangladesh (1993, 1996, 1999, 2011), Benin (2001, 2012), Bolivia (1994, 1998, 2008), Brazil (1996), Burkina Faso (2010), Burundi (2010), Cameroon (1998), Central Africa (1995), Colombia (1990, 1995, 2000, 2005, 2010), Comoros (1996), Congo (2007), Congo-Brazzaville (2005), Ivory Coast (1994, 1999, 2005), Dominican Republic (1996, 1999, 2002, 2007, 2013), Egypt (1995, 2000, 2005, 2008), Ethiopia (2000, 2005, 2011), Gabon (2000), Ghana (1993, 1998, 2008), Guatemala (1998), Guinea (2005, 2012), Haiti (2000), Honduras (2005, 2011), India (2005), Indonesia (1997, 2007, 2012), Jordan (1990, 1997, 2002, 2007, 2012), Kazakhstan (1995, 1999), Kenya (1993, 1998), Kyrgyz Republic (1997), Lesotho (2009), Liberia (2007), Madagascar (1997, 2009), Malawi (2000, 2010), Mali (1996, 2001, 2006, 2013), Moldova (2005), Morocco (1992), Mozambique (1997, 2009), Namibia (1992, 2007), Nepal (1996, 2001, 2011), Nicaragua (1998, 2001), Niger (2006, 2012), Nigeria (1990, 2010), Pakistan (1990, 2006, 2012), Paraguay (1990), Peru (1991, 1996, 2000, 2009, 2012), Philippines (1993, 1998, 2008, 2013), Rwanda (2000, 2007, 2010), São Tomé and Príncipe (2008), Senegal (1997, 2011), Sierra Leone (2008), South Africa (1998), Swaziland (2007), Tajikistan (2012), Tanzania (1999, 2008, 2013), East Timor (2009), Turkey (1993), Uganda (1995, 2001, 2006, 2009, 2011), Ukraine (2007), Uzbekistan (1996), Vietnam (1997, 2002, 2005), Zambia (1996, 2002, 2007).

Source: author calculations. 
The following regression analysis is applied to the data:

$$
\begin{aligned}
& \text { Country-level: } \mathrm{AF}_{\mathrm{i}}=\alpha_{\mathrm{o}}+\alpha_{1} \mathrm{INE}_{\mathrm{i}}+\alpha_{2} \text { Income }_{\mathrm{i}}+\alpha_{3} \text { controls }_{\mathrm{i}}+\mathrm{e}_{\mathrm{i}} \\
& \text { Multilevel: } \mathrm{P}\left(\mathrm{AF}_{\mathrm{ij}}=1\right)=\mathrm{f}\left(\alpha_{\mathrm{o}}+\alpha_{1} \mathrm{INE}_{\mathrm{i}}+\alpha_{2} \text { Income }_{\mathrm{ij}}+\alpha_{3} \text { controls }_{\mathrm{ij}}+\mathrm{e}_{\mathrm{i}}\right)
\end{aligned}
$$

Where $A F$ stands for adolescent fertility (fertility ratio on regression 1 and a dichotomous variable for being a mother on regression 2), $i$ indexes the surveys (i.e., country and year), INE stands for the Gini index of income inequality, income stands for country-level mean income on regression 1 and individual-level income on regression $2, e$ is a random perturbation at the country-level, controls include region and survey year, both categorical variables, and also includes income $_{i}$ on regression $2 ; A F_{i}$ is not included as a control on regression 2 because, for being a country-level measure of adolescent fertility, it would leave no room for other country-level predictors, as $I N E_{i}$, for example. The parameters $\alpha$ and $\beta$ are estimated by ordinary least squares, in regression 1, and by maximum likelihood (random effects logistic model) in regression 2.

As it is necessary to model a nonlinear effect of individual income on adolescent fertility, trying to control a possible concavity induced effect of income inequality on adolescent fertility, income squared is also included in regression 2 . Other alternatives, such as fractional polynomials, were also explored with similar results.

Income inequality and mean income data come from the World Bank. Income inequality was measured by the "Gini index of income inequality." As some criticisms regarding the Gini coefficient point at its lack of sensibility at the extreme values of income distribution, results were also obtained based on the 20/20 income ratio (average income in the $20 \%$ of the population with the higher income over the average in the lowest $20 \%$, a common measure of income inequality). Mean income is measured by “annual gross national income per capita, purchasing power parity (current international \$)”. All country-level data was accessed as of February 2015.

To explore the stability of results, all surveys are analyzed both together and separately for four regions: Latin America, Asia, Africa, and Middle East.

\section{Results}

Table 1 shows the usual low income of African countries, and the usual high income inequality of Latin American countries. It should be noted, however, that the descriptive statistics in Table 1 do not represent the entire region; they arise from a selection of developing countries, as included in the DHS.

Table 2 shows the results of country and multilevel model estimates using the data in this study. Both types of models showed that higher income inequality predicts lower adolescent fertility. In the country-level analysis, sample sizes were low in each region, as is usual in this type of analysis, but the significant results for Asia, Africa, and all regions combined confirmed the negative association. Replacing the Gini index by the 20/20 income-group ratio of income yielded very similar results (not shown).

The comparison of results showed a lower impact of income inequality on the multilevel analysis, but the dependent variable was not exactly equal (ratio of children over adolescents on the countrylevel, and "having at least one child" in the multilevel). However, both models showed statistically significant results in Asia, Africa, and all regions combined.

An exercise of predicting probabilities after the multilevel estimation showed that a $1 \%$ increase in the Gini index, from its mean value, keeping all the other variables at their mean values, implies an absolute decrease of the predicted proportion of adolescents with children by $0.49 \%, 0.11 \%$, and $0.10 \%$ for Asia, Africa, and all regions combined (the ones that attained statistically significant results), respectively. As a reference, the average proportion of adolescents with children, as shown in Table 1, was $18 \%$.

The effect of individual income on the multilevel model was highly significant and negative, meaning that individuals placed higher in the wealth index ladder have a significantly lower probability of being a mother. Estimations in which the quadratic structure was replaced with fractional polynomials were also analyzed, reaching the same conclusions.

Across all regressions, average income showed no statistical association with adolescent fertility; this result remained consistent throughout the study. 


\section{Table 2}

Estimated coefficients from multilevel logistic regression of adolescent fertility on income inequality plus controls.

\begin{tabular}{|c|c|c|c|c|c|}
\hline \multirow[t]{2}{*}{ Dependent variable } & \multicolumn{5}{|c|}{ Adolescent fertility } \\
\hline & Latin America & Asia & Africa & Middle East & All \\
\hline \multicolumn{6}{|l|}{ Country-level analysis } \\
\hline Number of observations & 26 & 20 & 65 & 20 & 131 \\
\hline Income inequality (Gini) * & $\begin{array}{c}0.07 \\
(-1.20 ; 0.26)\end{array}$ & $\begin{array}{c}-2.34 \\
(-4.34 ;-0.34)\end{array}$ & $\begin{array}{c}-\mathbf{0 . 4 7} \\
(-0.83 ;-0.11)\end{array}$ & $\begin{array}{c}1.62 \\
(-0.35 ; 3.63)\end{array}$ & $\begin{array}{c}-\mathbf{0 . 4 0} \\
(-0.76 ;-0.04)\end{array}$ \\
\hline Average income ** & $\begin{array}{c}0.01 \\
(-0.07 ; 0.09)\end{array}$ & $\begin{array}{c}-0.55 \\
(-1.05 ; 0.05)\end{array}$ & $\begin{array}{c}0.01 \\
(-0.01 ; 0.03)\end{array}$ & $\begin{array}{c}0.18 \\
(-0.18 ; 0.54)\end{array}$ & $\begin{array}{c}0.03 \\
(-0.07 ; 0.13)\end{array}$ \\
\hline \multicolumn{6}{|l|}{ Multilevel analysis } \\
\hline Number of observations & 110,957 & 76,813 & 157,304 & 19,685 & 364,759 \\
\hline Income inequality (Gini) * & $\begin{array}{c}-0.00 \\
(-0.00 ; 0.00)\end{array}$ & $\begin{array}{c}-0.14 \\
(-0.24 ;-0.04)\end{array}$ & $\begin{array}{c}-0.02 \\
(-0.04 ;-0.00)\end{array}$ & $\begin{array}{c}0.05 \\
(-0.05 ; 0.15)\end{array}$ & $\begin{array}{c}-0.02 \\
(-0.04 ;-0.00)\end{array}$ \\
\hline Country-level income $* \star \star$ & $\begin{array}{c}-0.17 \\
(-5.17 ; 0.33)\end{array}$ & $\begin{array}{c}0.40 \\
(-1.60 ; 2.40)\end{array}$ & $\begin{array}{c}0.15 \\
(-0.45 ; 1.75)\end{array}$ & $\begin{array}{c}1.23 \\
(-0.57 ; 1.97)\end{array}$ & $\begin{array}{c}0.07 \\
(-0.04 ; 0.24)\end{array}$ \\
\hline Individual income ** & $\begin{array}{c}-\mathbf{2 . 4 7} \\
(-2.73 ; 2.23)\end{array}$ & $\begin{array}{c}-1.96 \\
(-2.36 ;-1.56)\end{array}$ & $\begin{array}{c}-1.82 \\
(-2.02 ;-1.62)\end{array}$ & $\begin{array}{c}-1.03 \\
(-1.93 ;-0.05)\end{array}$ & $\begin{array}{c}-2.00 \\
(-2.20 ;-1.80)\end{array}$ \\
\hline
\end{tabular}

* Data from the World Bank 25;

** Relative within-country ranking of wealth index; the squared variable was also included in the regression but not reported due to readability; *** GNP per capita, purchasing power parity (current international \$) from the World Bank 25.

Note: country-level analysis focuses on adolescent fertility rates by standard regression, and multilevel analysis focuses on adolescent motherhood (1: having a least one child, 0 : having no child) by a logit model with random effects per survey; parameters are not comparable between these models. All controls are omitted from the table (age, region, and year dummies; and country-level income squared in the multilevel analysis).

Source: author calculations.

\section{Discussion}

Among a large sample of individuals from different low-income countries, this study finds a statistically significant effect of income inequality on adolescent fertility. Unlike the current evidence, mostly based on middle to high-income countries and country-level analysis, the direction of the effect is negative. Country-level (one observation per country) and multilevel (one observation per respondent) analyses reach basically the same results. Repeating the analysis in this study for early adolescents (15 to 16 years old) and late adolescents (18 to 19 years old) produces very closely the same results.

Negative signs on the inequality well-being association have been found before 9,15,16,26, and it is not clear why this is the case. One possible reason for the results in this study is the association between early stages of development and economic inequality. The results in this study are visible not only among adolescents but up to the age of 29 as well, and early stages of development are associated with both higher inequality and lower fertility $21,27,28,29,30$, among other reasons, because lower birth rates could increase growth but rise short term inequality ${ }^{31}$. Another possible reason is the weak association of income inequality with several dimensions that are determinant for adolescent health, which increases the change of spurious income inequality-adolescent fertility associations. Among 13 family indicators, only "two indicators [show a positive] association with income inequality, most indicators do not show a robust link, [and] some have [even] a negative correlation" 15 (p. 1), and, among school age children in rich societies 11, 29/37 indicators of well-being show no association with income inequality.

In addition, results show no statistical association between average income and adolescent fertility. This might seem counterintuitive, since it is clear that adolescent fertility is higher in poorer areas of the world, but it is possible that, within countries in relatively similar stages of development, this 
association will vanish. In fact, two studies that included both rich and poor countries found that average income played a clear role 12,13 , while three studies that focused only on rich societies did not $11,15,16$.

The essential lesson from this empirical exercise is the complex association between income inequality and adolescent fertility. The overall conceptual framework surrounding the empirical evidence is vague, and our results place additional caution on the interpretation of the association itself. At the same time that some reasons can explain the negative income inequality-adolescent fertility association in low-income countries, another group of reasons might explain the positive income inequality-adolescent fertility association in high-income ones. Some of them are purely methodological, such as the sample size, the quality of data, the lack of relevant controls, the complexity of multilevel models 32 , and the availability of internationally comparable measures of individual income, while others call the general idea of the income inequality-adolescent fertility relationship into question. Social goods, such as trust and cohesion, and psycho-social stress, such as lack of decision power, might damage the health of individuals, but income inequality could as well capture ethnic or cultural factors or nonlinearities in the association of economic resources and health, for example.

\section{Contributors}

R. Castro and E. Fajnzylber collaborated across the entire article.

\section{Acknowledgments}

We thank Fondo Nacional de Desarrollo Científico y Tecnológico (FONDECYT, grant \#11130301) for the financial support.

\section{References}

1. Rowlingson K. Does income inequality cause health and social problems? http://www. jrf.org.uk/sites/files/jrf/inequality-incomesocial-problems-full.pdf (accessed on 01/ Sep/2016).

2. Wilkinson RG, Pickett KE. Income inequality and population health: a review and explanation of the evidence. Soc Sci Med 2006; 62:1768-84.

3. Erreygers G, van Ourti T. Measuring socioeconomic inequality in health, health care and health financing by means of rank-dependent indices: a recipe for good practice. $J$ Health Econ 2001; 30:685-94.

4. Lynch J, Smith GD, Harper SA, Hillemeier M, Ross N, Kaplan GA, et al. Is income inequality a determinant of population health? Part 1. A systematic review. Milbank Q 2004; 82:5-99.

5. Wagstaff A, Paci P, van Doorslaer E. On the measurement of inequalities in health. Soc Sci Med 1991; 33:545-57.

6. Subramanian SV, Kawachi I. Income inequality and health: what have we learned so far? Epidemiol Rev 2004; 26:78-91.

7. Wagstaff A, van Doorslaer E. Income inequality and health: what does the literature tell us? Annu Rev Public Health 2000; 21:543-67.

8. Leigh A, Jencks C, Smeeding TM. Health and economic inequality. In: Salverda W, Nolan B, Smeeding TM, editors. The Oxford handbook of economic inequality. Oxford: Oxford University Press; 2009. p. 384-405. 
9. Porter ME, Stern S, Green M. Social progress index 2015: executive summary. http:// www.socialprogressimperative.org/system/re sources/W1siZiIsIjIwMTUvMDQvMDgvM TUvMjkvNTQvNTkyL1NQSV8yMDE1X OVYRUNfU1VNTUFSWS 5 wZGYiXV0/ SPI\%202015\%20EXEC\%20SUMMARY.pdf (accessed on 01/Sep/2016).

10. Dorling D, Mitchell R, Pearce J. The global impact of income inequality on health by age: an observational study. BMJ 2007; 335:873.

11. Pickett KE, Wilkinson RG. Child wellbeing and income inequality in rich societies: ecological cross sectional study. BMJ 2007; 335:1080.

12. Viner RM, Ozer EM, Denny S, Marmot M, Resnick M, Fatusi A, et al. Adolescence and the social determinants of health. Lancet 2012; 379:1641-52.

13. Santelli JS, Sharma V, Viner R. 3. Inequality, national wealth, economic development and global trends in teenage birth rates, 1990(2010). J Adolesc Health 2013; 52(2 Suppl 1):S4-5.

14. Chiavegatto Filho AD, Kawachi I. Income inequality is associated with adolescent fertility in Brazil: a longitudinal multilevel analysis of 5,565 municipalities. BMC Public Health 2015; 15:103.

15. Calvert E, Fahey T. Income inequality and the family. GINI Discussion Paper, 75. http://giniresearch.org/articles/papers (accessed on 01/ $\mathrm{Sep} / 2016)$.

16. Pickett KE, Mookherjee J, Wilkinson RG. Adolescent birth rates, total homicides, and income inequality in rich countries. Am J Public Health 2005; 95:1181-3.

17. McQueston K, Silverman R, Glassman A. Adolescent fertility in low-and middle-income countries: effects and solutions. Washington DC: Center for Global Development; 2012. (Working Paper, 295).

18. Lundborg P, Nilsson A, Rooth DO. Adolescent health and adult labor market outcomes. J Health Econ 2014; 37:25-40.

19. Carmignani F, Shankar S, Tan EJ, Tang KK. Identifying covariates of population health using extreme bound analysis. Eur J Health Econ 2014; 15:515-31.

20. Rutstein SO, Johnson K, Measure OM. The DHS wealth index. Calverton: ORC Macro; 2004. (DHS Comparative Reports, 6).

21. Macan VJ, Deluna RJ. Relationship of income inequality and labor productivity on fertility in the Philippines: 1985-(2009). MPRA Paper, 51679. https://mpra.ub.uni-muenchen. de/51679/ (accessed on 01/Sep/2016).
22. Kondo N, Sembajwe G, Kawachi I, van Dam RM, Subramanian SV, Yamagata Z. Income inequality, mortality, and self rated health: meta-analysis of multilevel studies. BMJ 2009; 339:b4471.

23. Blakely TA, Kawachi I. What is the difference between controlling for mean versus median income in analyses of income inequality? J Epidemiol Community Health 2001; 55:352-3.

24. Davila RL, McCarthy AS, Gondwe D, Kirdruang P, Sharma U. Water, walls and bicycles: wealth index composition using census microdata. Minneapolis: Minnesota Population Center, University of Minnesota; 2014. (MPC Working Papers, 2014-7).

25. World Bank. Quantitative techniques for health equity analysis. http://siteresources. worldbank.org/INTPAH/Resources/Publica tions/Quantitative-Techniques/health_eq_ tn07.pdf (accessed on Feb/2015).

26. Due P, Damsgaard MT, Rasmussen M, Holstein BE, Wardle J, Merlo J, et al. Socioeconomic position, macroeconomic environment and overweight among adolescents in 35 countries. Int J Obes (2009); 33:1084-93.

27. Guest R, Swift R. Fertility, income inequality, and labour productivity. Oxf Econ Pap 2008; 60:597-618.

28. Ehrlich I, Kim J. The evolution of income and fertility inequalities over the course of economic development: a human capital perspective. J Hum Cap 2007; 1:137-74.

29. Gründler K, Scheuermeyer P. Income inequality, economic growth, and the effect of redistribution. Würzburg: University of Würzburg; 2014. (Würzburg Economic Papers, 95).

30. Sato Y, Tabata K, Yamamoto K. Technological progress, income inequality, and fertility. J Popul Econ 2008; 21:135-57.

31. Bloom DE, Canning D, Fink G, Finlay JE. Microeconomic foundations of the demographic dividend. Boston: School of Public Health, Harvard University; 2012. (PGDA Working Paper, 93).

32. Larsen K, Petersen JH, Budtz-Jørgensen E, Endahl L. Interpreting parameters in the logistic regression model with random effects. Biometrics 2000; 56:909-14. 


\section{Resumen}

El conocido gradiente socioeconómico en la salud no significa que la desigualdad de renta, por sí sola, tenga algún efecto sobre el bienestar. Existen evidencias de una asociación positiva entre desigualdad de renta y fertilidad en la adolescencia en diversos países, pero este importante descubrimiento requiere más investigaciones en los países de baja renta. El estudio aplica la regresión logística multivariada al análisis de la fertilidad en la adolescencia y la desigualdad de renta, ambas a nivel nacional, además de la renta individual y controles, utilizando datos de las Encuestas de Demografía y Salud. Se encontró una asociación negativa entre desigualdad de renta y fertilidad en la adolescencia en países de baja renta, después de ajustar por renta (OR =0,981; IC95\%: 0,9630,999). Los mismos resultados fueron constatados para medidas diferentes y sub-muestras diferentes de estos países. Por tanto, la asociación internacional entre desigualdad de renta y fertilidad en la adolescencia parece ser más compleja de lo que se pensaba anteriormente.

Inequidad Social; Fertilidad; Países en Desarrollo; Adolescente

\section{Resumo}

O conhecido gradiente socioeconômico na saúde não significa que a desigualdade de renda, por si só, tenha qualquer efeito sobre o bem-estar. Há evidência de uma associação positiva entre desigualdade de renda e fertilidade na adolescência em diversos países, mas esse importante achado requer mais averiguação nos países de baixa renda. $O$ estudo aplica a regressão logística multivariada à análise da fertilidade na adolescência e a desigualdade de renda, ambas em nível nacional, além da renda individual e controles, utilizando dados dos Inquéritos de Demografia e Saúde. Foi encontrada uma associação negativa entre desigualdade de renda e fertilidade na adolescência em países de baixa renda, depois de ajustar para renda $(O R=$ 0,981; IC95\%: 0,963-0,999). Os mesmos resultados foram constatados para medidas diferentes e sub-amostras diferentes dos países. Portanto, a associação internacional entre desigualdade de renda e fertilidade na adolescência parece ser mais complexa do que se pensava anteriormente.

Iniquidade Social; Fertilidade; Países em Desenvolvimento; Adolescente

Submitted on 09/Dec/2015

Final version resubmitted on 27/Oct/2016

Approved on 28/Nov/2016 